
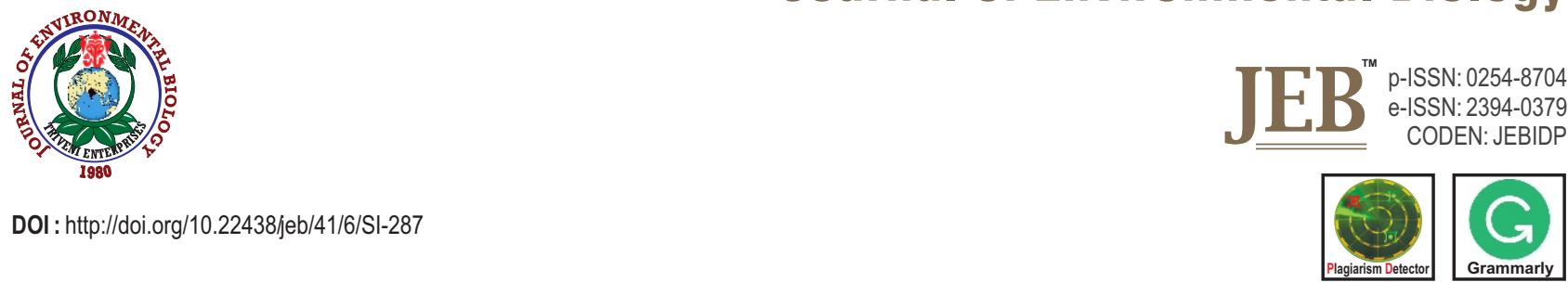

\title{
Soil organic carbon storage and factors affecting its distribution paddy and forest soil of Jorhat District of Assam
}

\author{
R. Baruah ${ }^{1 *}$, B.K. Medhi ${ }^{2}$ and D. Bhattacharyya ${ }^{2}$ \\ ${ }^{1}$ Regional Agril Research Station, Diphu (Karbi-Anglog)-782 460, India \\ ${ }^{2}$ Department of Soil Science, Assam Agricultural University, Jorhat-785 013, India \\ ${ }^{*}$ Corresponding Author Email : rashmi.baruah@aau.ac.in
}

Accepted: 30.10 .2020

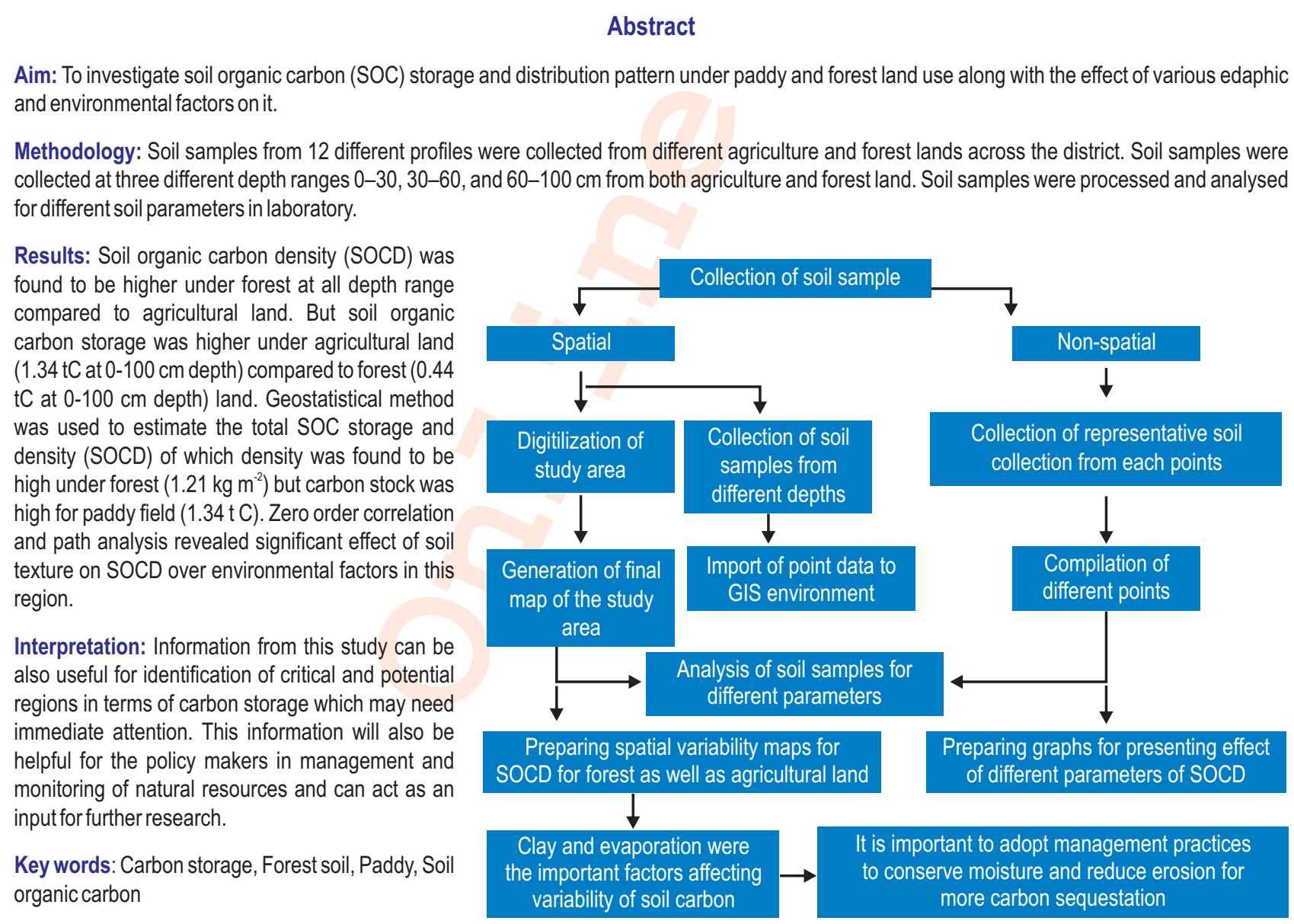

How to cite : Baruah, R., B.K. Medhi and D. Bhattacharyya: Soil organic carbon storage and factors affecting its distribution in paddy and forest soil of Jorhat District of Assam. J. Environ. Biol., 41, 1798-1810 (2020). 


\section{Introduction}

Soil carbon stock (SCS) estimation is a much-discussed topic in present era due to its critical role in the global carbon cycle. Because of the important role of soil organic carbon (SOC) as well as its large fraction in terrestrial ecosystems, a slight change in SOC stock may influence global climate (Uri, 2000). Although a lot of research is being conducted to estimate carbon stock all over the world, record of carbon stock of this region is limited due to various reasons like, inaccessibility, large heterogeneity of soil etc. According to a study reported by Baruah et al. (2017), the overall carbon stock for agricultural land of Jorhat district was $8.18 \mathrm{Tg}, 14.21 \mathrm{Tg}$ and $19.78 \mathrm{Tg}$ for $0-30 \mathrm{~cm}, 0$ $60 \mathrm{~cm}$ and $0-90 \mathrm{~cm}$, respectively.

Distribution and heterogeneity of SOC has been correlated with various climate factors, soil properties and land cover types (Yang et al., 2007) etc. North-East has unique place in the world (Dikshit 2014) as it has around one-third of India's total biodiversity (Choudhury et al., 2011) with highly variable climatic conditions. Both forestry and agricultural lands are dominant land use system of this region. According to the Kyoto Protocol, soils of both forest and agriculture may be considered as carbon sink, however, data show that forests are on an average greater SOC sinks in comparison with agricultural land uses (Jobbágy and Jackson, 2000). Various studies have reported that conversion of forested areas into cultivated agriculture has led to an overall decline in SOC stock in those soils (Zhang et al., 2012), due to changes in soil structure, diminished microbial activity, altered aeration and moisture regimes, reduced inputs of organic matter and more intense soil erosion (Kenye et al., 2019). But better land management practices can contribute to the improvement of the condition.

Estimation of carbon stock is costly and time-consuming task and is likely to get affected by many factors of uncertainty. For instance, increased temperatures may cause a not-linear carbon loss in combination with extreme drought, as reported in information derived from eddy-covariance studies across Europe in 2003 (Reichstein et al., 2006). As bulk density and organic carbon are correlated, changes in bulk density may induce changes in the mineral mass of soil both spatially and vertically, therefore, determination of bulk density at all sites is important, but bulk density values are absent in most databases. Similarly, soil texture, pH, CEC etc., also have direct or indirect effect on SOC. Several studies have shown that clay influences aggregation (Schlecht-Pietsch et al., 1994) and by increasing soil aggregation, clay content indirectly affects soil $\mathrm{C}$ storage by occluding organic materials, making them inaccessible to degrading organisms and their enzymes. Again, recalcitrant organic molecules are found to be often associated with silt and clay minerals (Paul and Clark, 1989). Therefore, we can easily say from these observations that soil texture provides chemical and physical protection of soil $\mathrm{C}$ stocks. Similarly, presence of exchange cations (eg, $\mathrm{Ca}, \mathrm{Al}, \mathrm{Fe}$ etc) protect SOC from microbial degradation through adsorption and aggregation (Krull et al., 2001) through clay-SOM complexes and cation bonding (Oades, 1995). Soil pH indirectly affects carbon storage of soil by controlling enzymatic activity of microbes. Dalal and Chan (2001) reported that low soil $\mathrm{pH}$ in natural ecosystems result in increasing SOC because soil microbial activity decreases as $\mathrm{pH}$ decreases.

Natural ecosystems like forest are mostly undisturbed and, hence, the maintenance of well-balanced carbon stock is easy compared to agricultural land. There are many reports on soil available carbon under different land uses and according to the report of Choudhury et al. (2013) North-east India showed the highest SOC stock in dense forest $(140.4 \mathrm{Tg})$ and least in shifting cultivation $(10.7 \mathrm{Tg})$ with total SOC stock of $339.82 \mathrm{Tg}$, irrespective of land use system. Similarly, a study from Mizoram (Kenye et al. 2019) showed that under shifting cultivation soil carbon stock decreased to maximum even more than paddy field. All these studies have carried out detail study of carbon stock and its spatial distribution under different land use systems. But these kind of information for Jorhat district is very limited. Moreover, rapid change of farm land, conversion of land use practices and decrease of forest cover have been observed in district, which raises the need for studying the current SOC storage and distribution as well as their associations with different edaphic and environmental factors so that regional soil carbon stock (SCS) can be determined. Therefore, this study was under taken to estimate SOC storage up to $1 \mathrm{~m}$ depth along with estimation of SOC storage and distribution mapping. Moreover, a comparison of SOC across different terrestrial land-cover types and assessment of impact of soil and environmental factors on variability of SOC storage was also examined.

\section{Materials and Methods}

Study area : Jorhat district is located between $26^{\circ} 37^{\prime} \mathrm{N}$ latitude and $27^{\circ} 20^{\prime} \mathrm{N}$ and $94^{\circ} 50^{\prime} \mathrm{E}$ and $93^{\circ} 57^{\prime} \mathrm{E}$ longitude, bounded by Lakhimpur district in north, Sivasagar in East, Golaghat district in west and Nagaland in south (Fig. 1). It is situated under Upper Brahmaputra valley zone of Assam, which is generally flat with some undulating foot hill areas. Out of total geographical area of about 2,851 sq km (2, 85,100 ha), the district has about 1.36 lakh ha $(47.8 \%)$ as net sown area and forests occupies about 0.22 lakh ha $(7.86 \%)$ of the district. District experiences $138.04 \mathrm{~cm}$ of mean annual rainfall (Fig. 2) with January being the coldest month having minimum average temperature of $11.6^{\circ} \mathrm{C}$ and August being the hottest month with an average maximum temperature of $31.8^{\circ} \mathrm{C}$. The relative humidity ranges from 52.34 per cent during February to 96.5 per cent during June-July. The elevation of district varies from 72 to $263.57 \mathrm{~m}$ above mean sea level (Fig. 1). The altitude of hills in the southern parts of district is $312 \mathrm{~m}$ above MSL. 

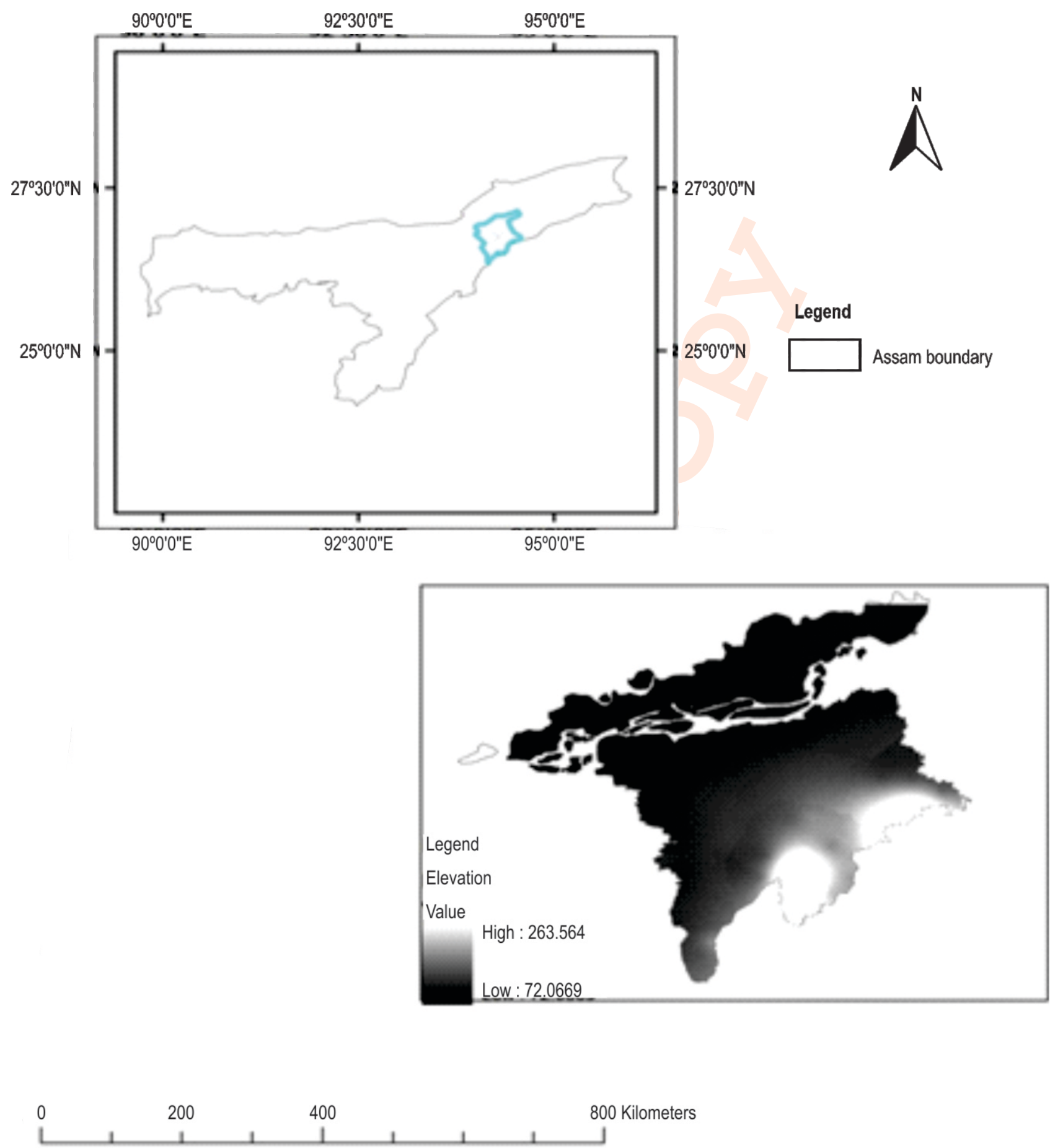

Fig. 1 : Location map of the study area.

Soil sampling and determination : Jorhat district is nearly flat with some elevation towards the south. Based on the physiography of district sampling, plots were decided and georeferenced soil samples were collected from an area of 10×10 $\mathrm{m}$ at every point during 2014-15 covering both paddy and forest lands of whole Jorhat district (Table 1). Within each sampling point, one soil profile dug out and soils were collected at 0-30, 30-
60 and $60-100 \mathrm{~cm}$ depth. Apart from soil profile, three other points were randomly selected within the sampling area and soil samples were collected at different depths with the help of augur. At each sampling site, the SOC content for each depth was represented by the average of SOC values of these spatially random profiles. Location details, sampling depth, date and land situation at the time of sampling were recorded while sampling. A 


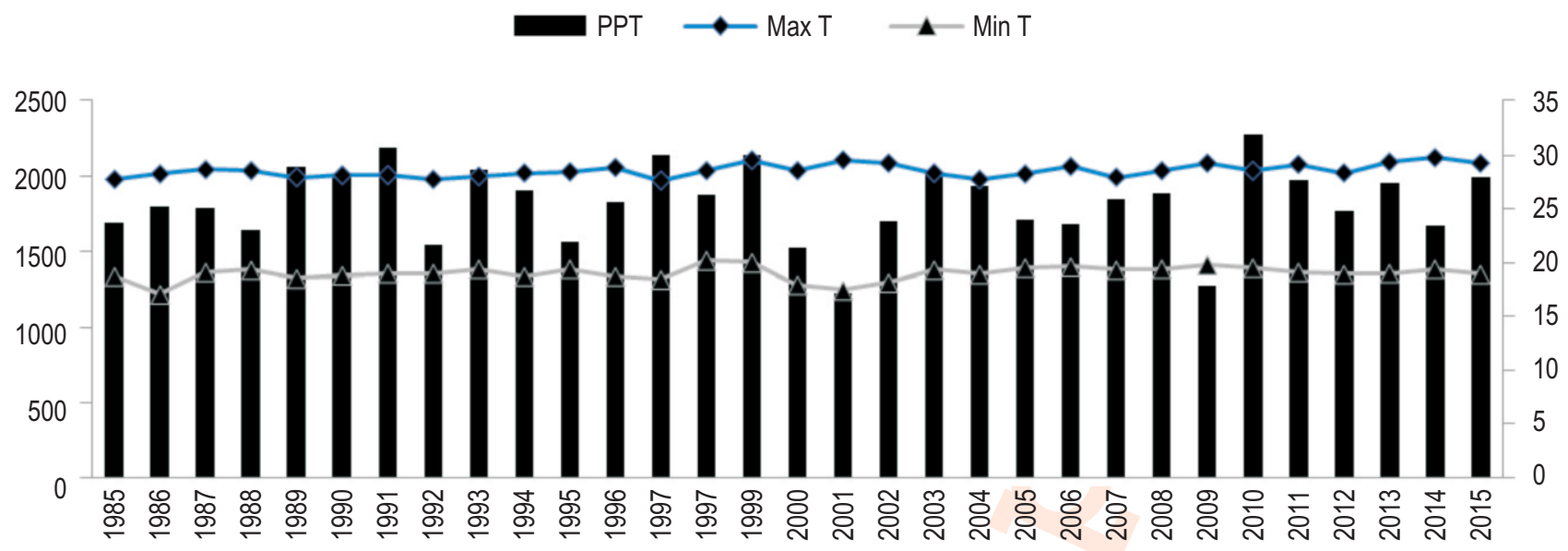

Fig. 2 : Total precipitation, maximum temperature and minimum temperature for last 30 years in Jorhat.

Table 1 : Site characteristics of sampling unit of Jorhat district

\begin{tabular}{lllll}
\hline Profiles & $\begin{array}{l}\text { Elevation } \\
(\mathbf{m}) \text { MSL }\end{array}$ & Slop $(\%)$ & Land use & Dominant plant type (at the time of sampling) \\
\hline P1 & $77-80$ & $1-2$ & Forest (small) & Stephegyneparvifolia, Dalbergia sissoo and Castanopsisindica \\
P2 & $70-72$ & $1-2$ & Paddy field & Fellow rice field \\
P3 & $120-126$ & $2-5$ & Forest & Ficus bengalensis, Dalbergia sissoo, Tectonagrandis and Castanopsisindica \\
P4 & $90-94$ & $1-2$ & Paddy & Fellow rice field \\
P5 & $147-155$ & $5-10$ & Forest & Madhucalatifolia, Stephegyneparvifolia, Dalbergia sissoo \\
P6 & $96-110$ & $1-2$ & Paddy & Fellow rice field \\
P7 & $65-68$ & $1-2$ & Forest & Bombax ceiba, Butea monosperma and Cassia fistula \\
P8 & $60-62$ & $0-1$ & Paddy & Fellow rice field \\
P9 & $75-77$ & $0-1$ & Paddy & Fellow rice field \\
P10 & $98-108$ & $2-5$ & Forest & Diospyros melanoxylon, Terminalia arjuna, Dipterocarpus retusus \\
P11 & $75-78$ & $1-2$ & Agriculture & Rabi vegetables \\
P12 & $51-54$ & $0-1$ & Agriculture & Freshly ploughed land after rice harvest \\
\hline
\end{tabular}

total of 12 composite soil profiles ( 7 composite profile for paddy field and 5 composite profile for forest land) were obtained and their locations were overlaid on a map (Fig. 3) showing paddy and forest areas of the district.

All soil samples were air dried and some part of the samples were oven dried at $105^{\circ} \mathrm{C}$ to determine bulk density. Bulk density was determined by clod method (Blake and Hartge, 1986). The other part of sample was processed for other analyses by removing visible plant debris and rock fragments and then grinded and sieved through $2 \mathrm{~mm}$ sieve. SOC concentration was measured by wet combustion with $\mathrm{K}_{2} \mathrm{Cr}_{2} \mathrm{O}_{7}$ (Walkley and Black, 1934). Hydrometer method was used to measure the soil texture (Bouyoucos, 1962), soil pH (Jackson, 1973) and cation exchange capacity (CEC) was measured by centrifuge method (Chapman, 1965).

Climate data : The maximum and minimum annual temperature (Max T and Min T), mean annual precipitation (MAP) and evaporation (E) were collected from the metrological station of Assam Agricultural University, Jorhat-13 for last 30 years (1985-
2015). To improve the accuracy of these data, data from Tokolai Tea Research Station, Jorhat was also collected for same period and any deviation were neutralized by using XLState® software.

Estimation of SOC storage : The soil organic carbon density (SOCD) and soil organic carbon (SOC) storage at depth $h(\mathrm{~cm})$ were calculated as follows (IPCC, 2003):

$$
\begin{aligned}
\operatorname{SOCD}_{\mathrm{h}} & =\sum_{\mathrm{SOC}_{\mathrm{h}}}=\operatorname{SOCD}_{\mathrm{h}} \times \frac{(1-\delta i \%) \times \text { Area }}{100}
\end{aligned}
$$

where, $n$ is the no of soil layer, $\delta i$ is the concentration of gravel larger than $2 \mathrm{~mm}$ in $\mathrm{i}^{\text {th }}$ soil layer (volume percentage), pi and Ci are the bulk density and SOC concentration $\left(\mathrm{g} \mathrm{kg}^{-1}\right)$ in $\mathrm{i}^{\text {th }}$ soil layer, respectively and $T \mathrm{i}$ is the thickness of $\mathrm{i}^{\text {th }}$ soil layer.

SOCD and SCS was estimated at each depth, followed by pooling of carbon density as well as carbon stock data for 


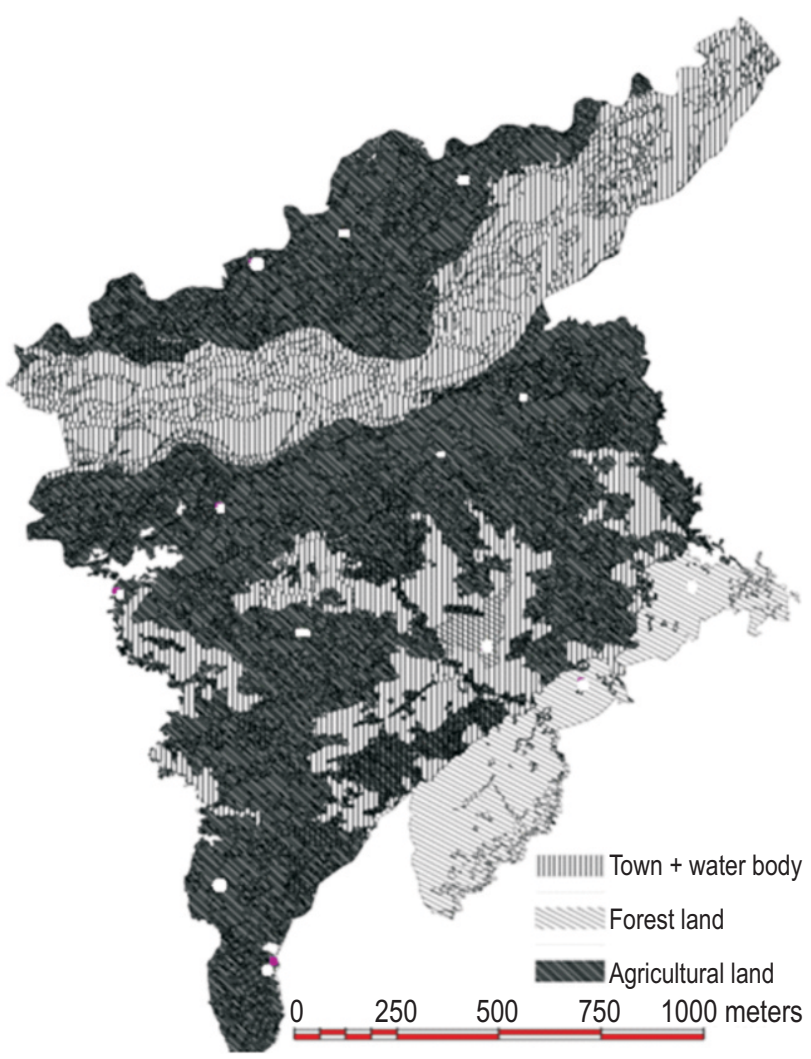

Fig. 3 : Profile locations for forest and paddy field (white dots are locations).

different depth range $(0-30.0-60$ and $0-100 \mathrm{~cm})$ was carried out for ease of representation in the form of map. Inverse Distance Weighting (IDW) interpolation was used to prepare spatial distribution map of SOCD. IDW is a geo-statistical method that is commonly used to interpolate an SOCD data set from discrete points to a spatially continuous surface (Khalil et al.2018). All the calculations for mapping SOCD within individual soil depth ranges were performed using Arc GIS software (Version 10.1).

Statistical analyses : Descriptive statistics along with analysis of variance (ANOVA) was carried out using SPSS v20.0. The coefficient of determination $\left(R^{2}\right)$ and correlation coefficient $(r)$ were also obtained from regression and correlative analysis with SPSS software to describe the effect of individual controlling factors on SOCD, such as climatic factors and soil physicochemical parameters (sand, silt, clay, CEC, pH). Moreover, path analysis was performed to see the direct as well as indirect effect of different parameters on SOCD using SAS ${ }^{\circledast}$ software.

\section{Results and Discussion}

The SOCD of 12 sampling profiles varied widely within each soil depth range (Table 2). The median SOCD values of sampling profiles of paddy field for three depth range $(0-30,0-60$ and $0-100 \mathrm{~cm}$ ) were $0.30,0.59$ and $0.80 \mathrm{~kg} \mathrm{~m}^{-2}$ and standard deviation (SD) of the corresponding SOCD were $0.17,0.31$ and 0.40 , respectively. Skewness values indicated that $S O C D$ values were non-symmetrical and deviated positively from mean (Mirzaee et al., 2016) whereas kurtosis values indicated that distribution of SOCD at different depth ranges were platykurtic.

Similarly, for forest land, the median SOCD values for three soil depth ranges were $0.53,0.78$ and $1.08 \mathrm{~kg} \mathrm{~m}^{-2}$ sequentially for $0-30,0-60$ and $0-100 \mathrm{~cm}$ depth, and SD of the corresponding SOCD were $0.13,0.22$ and 0.39 respectively (Table 2). Skewness values of SOCD showed positive deviation from mean, whereas kurtosis values for 0-30 and 0-60 cm indicated that SOCD distribution were platykurtic, but for 0-100 $\mathrm{cm}$ depth, distribution was leptokurtic.

The spatial variation of SOCD within soil depth range was apparent (Fig. 4a-4c). For soil depth range of $0-30 \mathrm{~cm}$, high SOCD values were present in southern part of the district due to presence of forest and along with some part of northern river bank due to alluvial deposit whereas for depth 0-60 cm higher values appeared within forest areas along with southern part. But, for depth $0-100 \mathrm{~cm}$, values higher than $0.90 \mathrm{~kg} \mathrm{~m}^{-2}$ SOCD appeared at south east corner along with northern river-bank (Guanet al. 2019). Within 0-30 cm depth, about $45.91 \%$ of areas of paddy field showed SOCD values within $0.2-0.3 \mathrm{~kg} \mathrm{~m}^{-2}$ followed by $\operatorname{SOCD}(20.65 \%)$ values of $0.3-0.4 \mathrm{~kg} \mathrm{~m}^{-2}$. But in case of $0-60 \mathrm{~cm}$, about $32.70 \%$ areas of paddy field showed SOCD value of $0.0-0.5$ $\mathrm{kg} \mathrm{m}^{-2}$ which was followed by SOCD range of 0.6-0.7 $\mathrm{kg} \mathrm{m}^{-2}$ covering area of $23.90 \%$ of total paddy area of the district. But, in case of $0-100 \mathrm{~cm}$, maximum area (49.32\%) came under SOCD range of $>0.90 \mathrm{~kg} \mathrm{~m}^{-2}$ followed by $0.60-0.70 \mathrm{~kg} \mathrm{~m}^{-2}$ covering area of $29.63 \%$ of total paddy area. Similarly, for forest land, within 0-30 $\mathrm{cm}$ depth, maximum area $(40.55 \%)$ came under SOCD range of $>0.50 \mathrm{~kg} \mathrm{~m}^{-2}$ followed by $0.40-0.50 \mathrm{~kg} \mathrm{~m}^{-2}$ which covered an area of $28.76 \%$ of total forest area of the district. For $0-60 \mathrm{~cm}$ depth, SOCD range $0.70-0.80 \mathrm{~kg} \mathrm{~m}^{-2}$ dominated $(42.67 \%$ ) the forest area of district followed by SOCD range $>0.80 \mathrm{~kg} \mathrm{~m}^{-2}$ covering an area of $39.46 \%$ of total forest area whereas for $0-100 \mathrm{~cm}$ depth range, SOCD value $>0.90 \mathrm{~kg} \mathrm{~m}^{-2}$ covered about $55.01 \%$ of the forest area of the district.

Mean Annual Precipitation (MAP) showed positive and significant correlation (Table 4) with SOCD $\left(r=0.266^{* *}\right)$ under forest but no correlation under paddy field (Table 4). But, depth wise analyses showed that MAP had a strong and significant corelation with SOCD at $0-30 \mathrm{~cm}\left(\mathrm{r}=0.341^{* *}\right.$ and $\left.314^{* *}\right)$ as well as 0 $60 \mathrm{~cm}\left(r=0.327^{* *}\right.$ and $\left.0.362^{* *}\right)$ depth ranges under forest and paddy land use (Table 4). This effect of MAP decreased when the whole $0-100 \mathrm{~cm}$ depth range was considered. Regression relationship among MAP and SOCD also showed similar pattern (Fig. 5b, 6b), which could be related to increase in net primary production (NPP) with precipitation (Cheng et al., 2014).This 


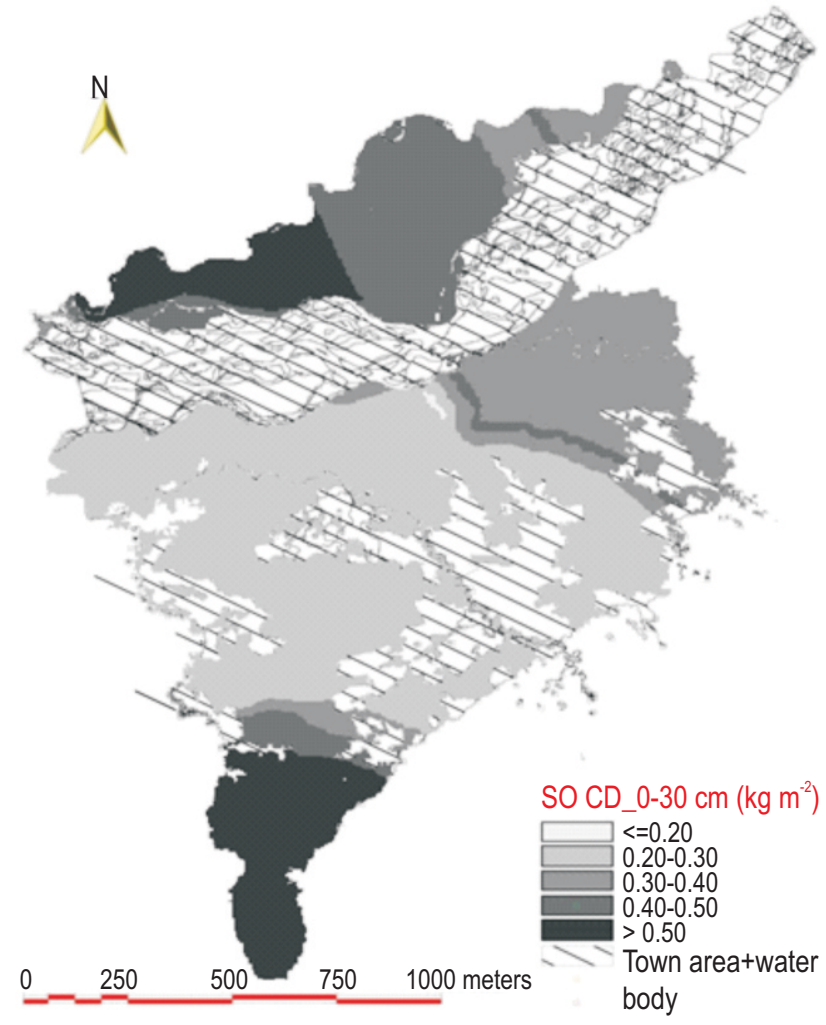

Fig. 4(a) : SOCD map for paddy and forest land at $0-30 \mathrm{~cm}$ depth.

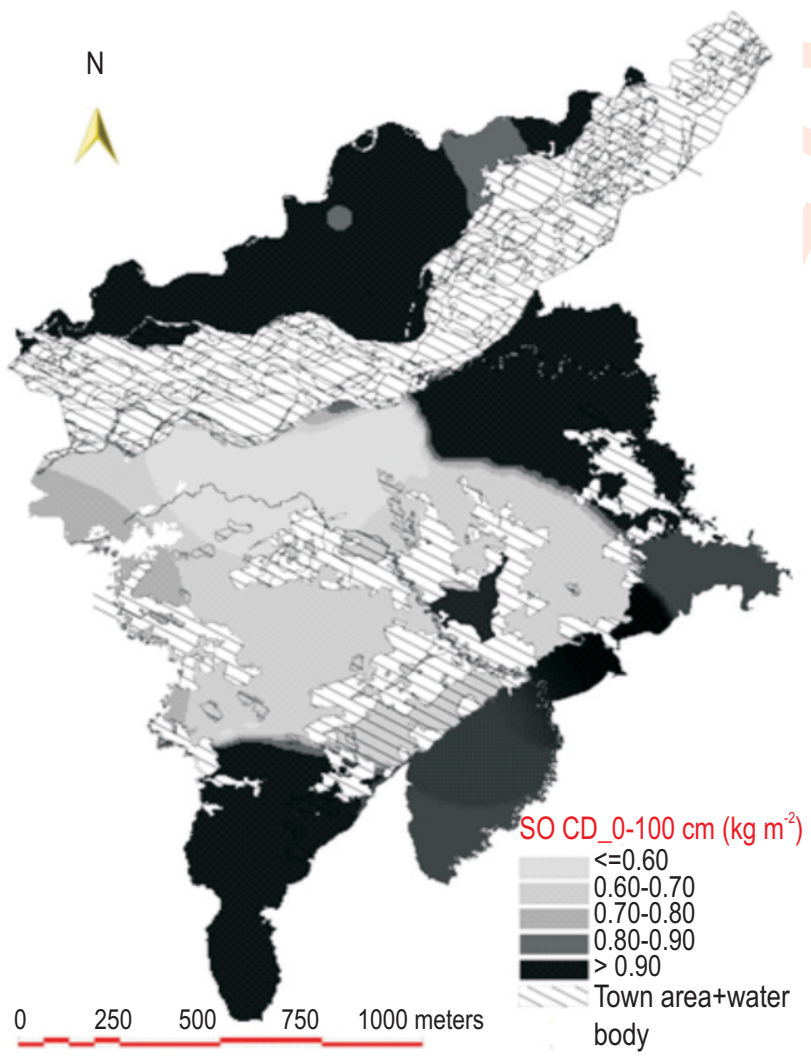

Fig. 4(c) : SOCD map for paddy and forest land at 0-60 cm depth.

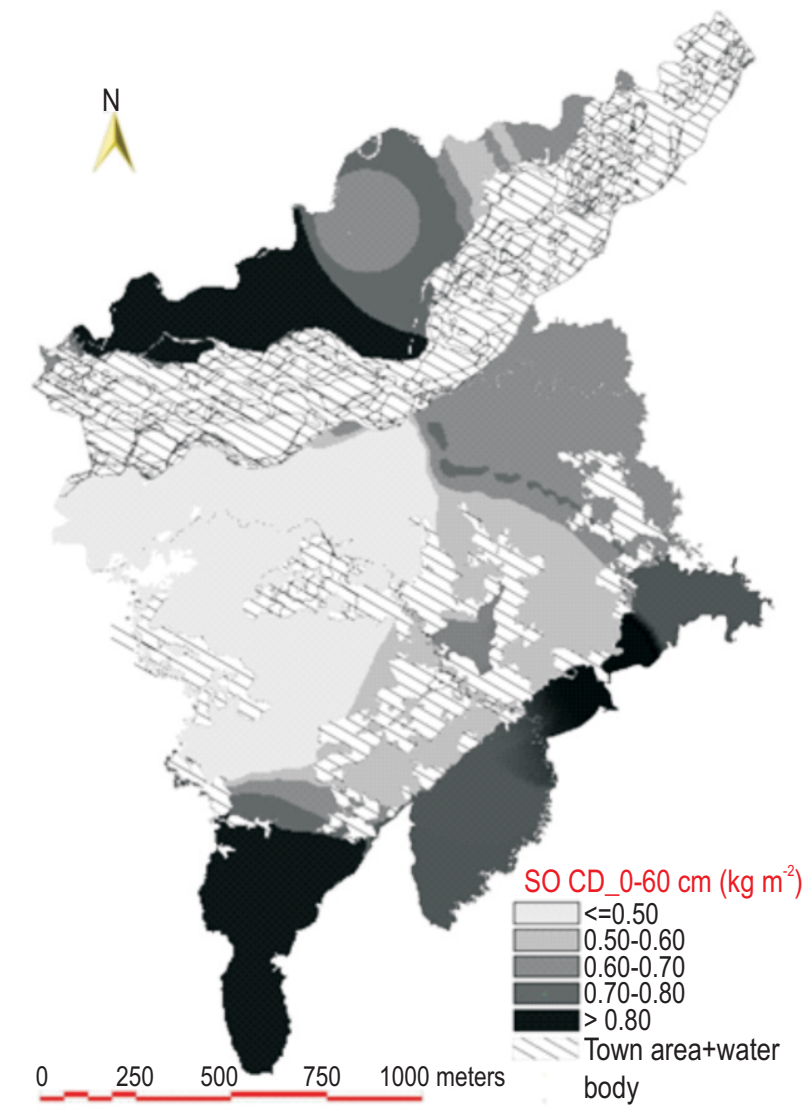

Fig. 4(b) : SOCD map for paddy and forest land at 0-60 cm depth

might be also because precipitation enhances tree biomass which induces accumulation of OC in soil (Yang et al., 2008). But with depth, the effect diminishes probably due to slower cycling of organic matter in deep soil layer (Jabbagy and Jackson, 2000) which can be attributed to low soil moisture in deeper layers (Mao et al., 2015) or may be due to soil buffering capacity which reduces the effect of environmental factors over SOC (Luo et al., 2009) at deeper depth.

Positive and significant effect $\left(r=0.386^{* *}\right)$ of mean annual temperature (MAT) was observed under forest (Table 4), but the effect increased with depth wise (Table 4) up to 0-100 cm under both land uses. Increasing effect of temperature on SOC with depth may be explained by the fact that Jorhat has warm and humid climate and its MAT is always greater than $4.6^{\circ} \mathrm{C}$ which increases $\mathrm{C}$-inputs that increases temperature induced rise in the soil decomposition rate (Yang et al., 2008). Increasing effect of temperature on SOCD can be also observed with the regression relationship (Fig 5b, 6b).

Evaporation showed $\AA=-0.482^{* *}$ and $-0.420^{* *}$ ) significant but negative correlation with SOCD (Table 4) under forest and paddy. But depth wise analysis showed (Table 4) 
Table 2 : Descriptive statistics of $S O C D$ at different soil depth ranges $(0-30,0-60$ and $0-100 \mathrm{~cm})$ for both paddy and forest land covertypes

\begin{tabular}{|c|c|c|c|c|c|c|}
\hline \multirow[b]{2}{*}{ Depth } & \multicolumn{5}{|c|}{$\operatorname{SOCD}\left(\mathrm{Kg} \mathrm{m}^{-2}\right)$} & \multirow[b]{2}{*}{ Skew } \\
\hline & Min & Max & Median & SD & Kur & \\
\hline \multicolumn{7}{|c|}{ Paddy } \\
\hline $0-30$ & 0.20 & 0.62 & 0.30 & 0.17 & -1.36 & 0.71 \\
\hline $0-60$ & 0.34 & 1.15 & 0.59 & 0.31 & -0.66 & 0.94 \\
\hline $0-100$ & 0.52 & 1.58 & 0.80 & 0.40 & -0.44 & 0.97 \\
\hline \multicolumn{7}{|c|}{ Forest } \\
\hline $0-30$ & 0.26 & 0.60 & 0.53 & 0.13 & 2.25 & -1.45 \\
\hline $0-60$ & 0.53 & 1.13 & 0.78 & 0.22 & 0.61 & 0.61 \\
\hline $0-100$ & 0.91 & 1.89 & 1.08 & 0.39 & 4.11 & 1.97 \\
\hline
\end{tabular}

Table 3 : Mean SOCD and SOC storage for both agricultural and forest land-cover types in Jorhat district

\begin{tabular}{|c|c|c|c|c|c|c|c|}
\hline \multirow[t]{2}{*}{ Land cover types } & \multirow[t]{2}{*}{ Area (Sq km) } & \multicolumn{3}{|c|}{$\operatorname{SOCD}\left(\mathrm{kg} \mathrm{m}^{-2}\right)$} & \multicolumn{3}{|c|}{ SOC storage (t C) } \\
\hline & & $0-30$ & $0-60$ & $0-100$ & $0-30$ & $0-60$ & $0-100$ \\
\hline Agriculture & 1460.92 & $0.38^{\mathrm{a}}$ & $0.65^{\mathrm{a}}$ & $0.92^{\mathrm{a}}$ & $0.55^{\mathrm{a}}$ & $0.95^{\mathrm{a}}$ & $1.34^{\mathrm{a}}$ \\
\hline Forest & 362.72 & $0.48^{\mathrm{a}}$ & $0.79^{\mathrm{a}}$ & $1.21^{\mathrm{b}}$ & $0.17^{\mathrm{b}}$ & $0.29^{b}$ & $0.44^{\mathrm{b}}$ \\
\hline
\end{tabular}

$a, b=$ means across column under each carbon pool same letters do not differ significantly $(P<0.05)$

Table 4 : Correlation coefficients between SOCD and environmental factors in both land use systems

\begin{tabular}{|c|c|c|c|c|}
\hline Parameters & SOCD & $\operatorname{MAT}\left({ }^{\circ} \mathrm{C}\right)$ & Evaporation (mm) & $\operatorname{MAP}(\mathrm{mm})$ \\
\hline \multicolumn{5}{|c|}{ Forest } \\
\hline SOCD & 1 & & & \\
\hline $\operatorname{MAT}\left({ }^{\circ} \mathrm{C}\right)$ & $0.386^{\star *}$ & 1 & & \\
\hline Evaporation (mm) & $-0.482^{\star *}$ & 0.002 & 1 & \\
\hline $\mathrm{MAP}(\mathrm{mm})$ & $0.266^{* *}$ & $-0.361^{* *}$ & -0.011 & 1 \\
\hline \multicolumn{5}{|c|}{ Paddy } \\
\hline SOCD & 1 & & & \\
\hline $\operatorname{MAT}\left({ }^{\circ} \mathrm{C}\right)$ & 0.031 & 1 & & \\
\hline Evaporation (mm) & $-0.420^{* *}$ & 0.002 & 1 & \\
\hline $\mathrm{MAP}(\mathrm{mm})$ & 0.002 & $-0.361^{* *}$ & -0.011 & 1 \\
\hline
\end{tabular}

${ }^{* *}$ significant at $5 \%$

negative but increasing effect of evaporation on SOCD with depth under forest, but for paddy significant negative correlation ( $r=$ $\left.0.480^{* *}\right)$ was recorded only at $0-30 \mathrm{~cm}$ depth range. This negative effect might be due to loss of moisture through evaporation that reduced the mineralization process (Amooh et al. 2015) and decreased SOC content in soil.

In this study, SOCD was found to have different levels of correlation with soil texture at different depth range which might be because of its role in water holding and decomposition of organic matter (Chaplot et al., 2010). SOCD was found to be significantly and positively correlated with clay $\left(r=0.440^{* *}\right.$ and $0.636^{* *}$; forest and paddy respectively) under both land uses (Table 6a, b). This trend fitted well when we investigated the depth wise correlation of clay and SOCD (Table5). But coefficient of determination $\left(R^{2}\right)$ showed that effect of clay on SOCD decreased with depth under forest but for paddy it decreased then increased for 0-100 cm depth range (Fig. 5a, 6a). The positive effect of clay can be explained by its ability to bind organic molecules and gives physical protection against further mineralization caused by microbial attack (Rice, 2002). Although, there was no correlation of SOCD and CEC under paddy (Table 6a) but effect of CEC (Table 6b) was quite prevalent under forest land $\left(r=0.368^{* *}\right)$. Moreover, depth wise correlation (Table 5) also showed similar pattern, except for paddy $\left(r=0.309^{* *}\right)$ a significant positive correlation was found for 0-30 cm depth. As we all know, CEC was highly affected by type and amount of clay in soil, therefore, the positive effect of CEC on SOCD might be due to contribution of clay towards CEC of soils (Gangopadhyay et al., 2016).

Sand had no significant effect on SOCD under forest land but it showed positive and significant correlation $\left(r=0.423^{* *}\right)$ 
Table 5 : Correlation coefficient of different factors with SOCD at different depth

\begin{tabular}{llll}
\hline Parameters & & Depth $(\mathrm{cm})$ & \\
\cline { 2 - 4 } & $0-30$ & $0-60$ & $\mathbf{0}-100$ \\
\hline & & Forest & \\
Sand $(\%)$ & -0.069 & -0.010 & 0.053 \\
Silt $(\%)$ & 0.202 & -0.225 & -0.372 \\
Clay $(\%)$ & $0.792^{* *}$ & 0.196 & $0.593^{* *}$ \\
CEC & $0.407^{* *}$ & $0.290^{* *}$ & $0.204^{*}$ \\
pH $(1: 2.5)$ & $0.909^{* *}$ & $0.722^{* *}$ & 0.148 \\
MAT $\left({ }^{\circ} \mathrm{C}\right)$ & $0.741^{* *}$ & $0.828^{* *}$ & $0.899^{*}$ \\
MAP $(\mathrm{mm})$ & $0.341^{* *}$ & $0.327^{*}$ & 0.035 \\
Evaporation $(\mathrm{mm})$ & $0.328^{* *}$ & $0.660^{* *}$ & $0.882^{*}$ \\
& & & \\
Sand $(\%)$ & $0.352^{* *}$ & -0.054 & -0.134 \\
Silt $(\%)$ & 0.043 & 0.191 & -0.145 \\
Clay $(\%)$ & $0.524^{* *}$ & $0.446^{* *}$ & $0.580^{* *}$ \\
CEC & $0.309^{* *}$ & 0.012 & 0.060 \\
pH $(1: 2.5)$ & $-0.461^{* *}$ & -0.122 & -0.169 \\
MAT $\left({ }^{0} \mathrm{C}\right)$ & $0.422^{* *}$ & $0.379^{* *}$ & $0.659^{* *}$ \\
MAP $(\mathrm{mm})$ & $0.314^{* *}$ & $0.362^{* *}$ & 0.121 \\
Evaporation $(\mathrm{mm})$ & $0.480^{* *}$ & 0.249 & $0.491^{*}$ \\
\hline
\end{tabular}

${ }^{* *}$ significant at $5 \%$

Table 6a: Correlation coefficients $(r)$ and Path analysis coefficients to SOCD of paddy field

\begin{tabular}{|c|c|c|c|c|c|c|c|c|}
\hline \multirow[t]{2}{*}{ Parameters } & \multirow[t]{2}{*}{ Correlation(r) } & \multirow[t]{2}{*}{ Direct effect } & \multicolumn{5}{|c|}{ Indirect effect } & \multirow[t]{2}{*}{ Total effect } \\
\hline & & & $\mathrm{pH}$ & Sand & Silt & Clay & CEC & \\
\hline $\mathrm{PH}$ & -0.062 & 0.206 & 一 & 0.1006 & -0.029 & -0.217 & -0.109 & 0.064 \\
\hline Sand & $0.423^{* *}$ & 1.006 & 0.492 & - & -0.691 & -0.679 & -0.776 & -0.174 \\
\hline Silt & 0.071 & 0.916 & -0.131 & -0.629 & - & 0.0588 & 0.570 & 0.067 \\
\hline Clay & $0.636^{* *}$ & 1.193 & -0.677 & -0.806 & 0.077 & - & 0.524 & 0.311 \\
\hline CEC & 0.000 & 0.330 & 0.175 & 0.155 & -0.006 & 0.845 & - & 0.121 \\
\hline
\end{tabular}

${ }^{* *}$ significant at $5 \%$

Table $6 \mathrm{~b}$ : Correlation coefficients $(r)$ and Path analysis coefficients to SOCD of forest land

\begin{tabular}{|c|c|c|c|c|c|c|c|c|}
\hline \multirow[t]{2}{*}{ Parameters } & \multirow[t]{2}{*}{ Correlation(r) } & \multirow[t]{2}{*}{ Direct effect } & \multicolumn{5}{|c|}{ Indirect effect } & \multirow[t]{2}{*}{ Total effect } \\
\hline & & & $\mathrm{pH}$ & Sand & Silt & Clay & CEC & \\
\hline $\mathrm{pH}$ & $0.289^{* *}$ & 0.806 & - & 0.492 & -0.131 & 0.677 & 0.175 & 0.281 \\
\hline Sand & -0.180 & 0.006 & 0.101 & - & -0.029 & -0.106 & -0.255 & -0.064 \\
\hline Silt & $-0.114^{*}$ & 0.186 & -0.029 & -0.091 & - & 0.077 & -0.205 & 0.067 \\
\hline Clay & $0.440^{* *}$ & 0.193 & -0.117 & -0.179 & 0.059 & - & -0.245 & 0.111 \\
\hline CEC & $0.368^{* *}$ & 1.030 & -0.109 & -0.776 & 0.570 & 0.524 & - & 0.153 \\
\hline
\end{tabular}

${ }^{* *}$ significant at $5 \%$

under paddy field (Table 6b). From the depth wise correlation analysis (Table 5), sand was found to have significant positive correlation with SOCD $\left(r=0.352^{* *}\right)$, but this correlation became negative and non-significant with depth, which might be related to indirect effect of aeration on decomposition of organic matter leading to build up of organic carbon in soil (Islam et al., 2014) and with depth aeration effect diminished. Likewise, $\mathrm{pH}$ showed positive and significant effect on SOCD under forest land $\left(r=0.289^{* *}\right)$ but no significant correlation was found under paddy. From depth wise analysis also, we found similar correlation, 

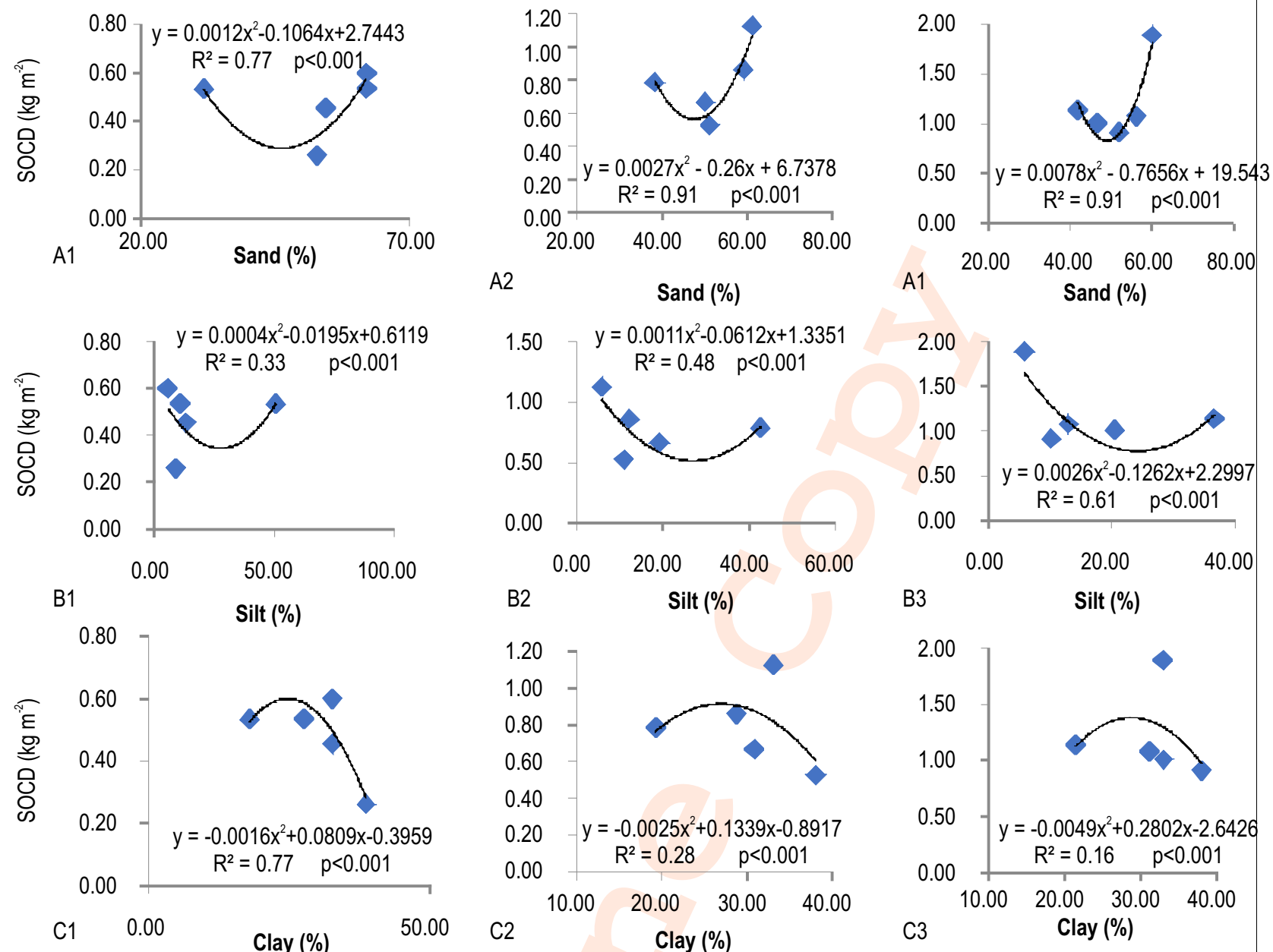

B2
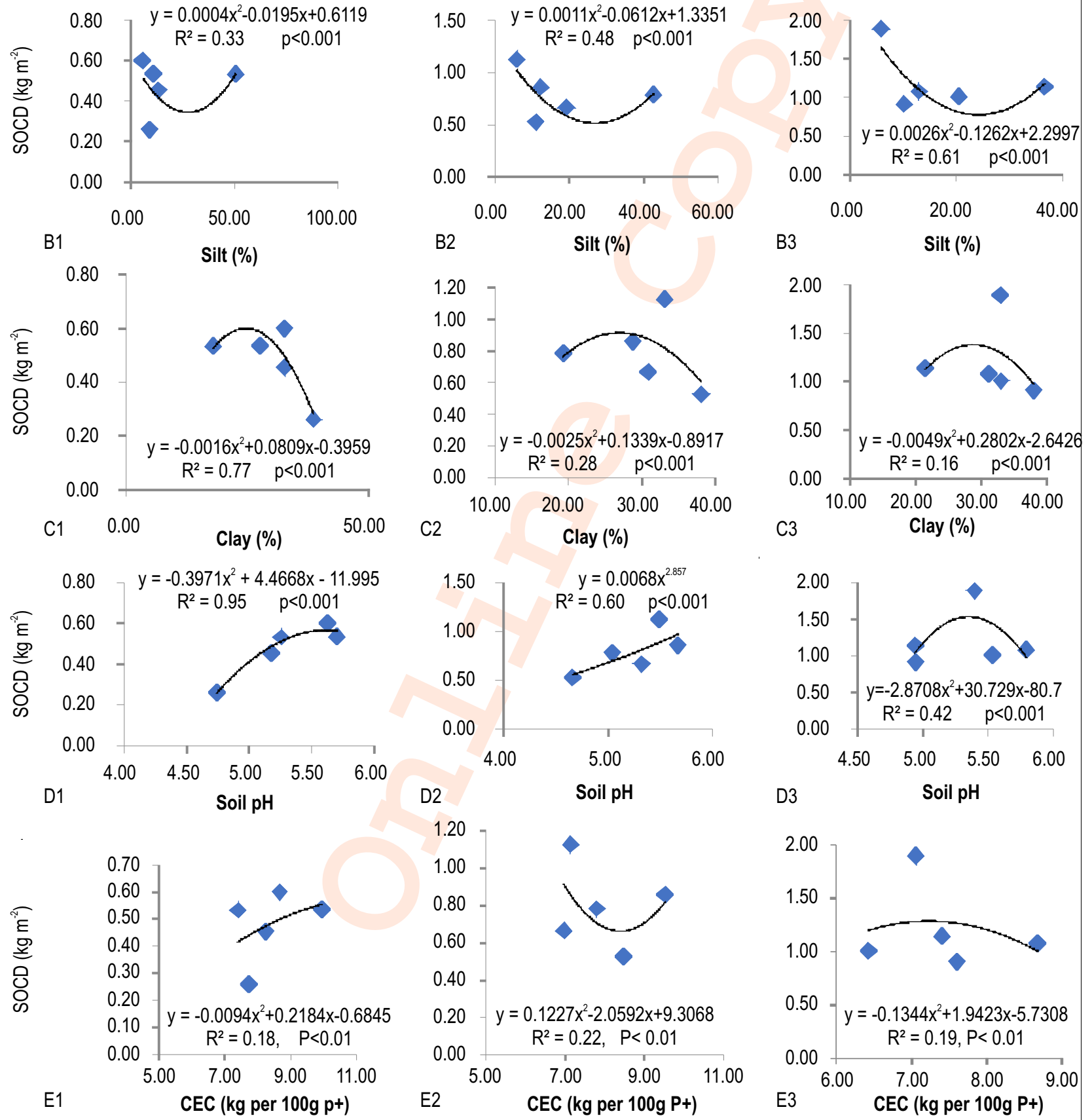

Fig. 5(a) : Relationship of SOCD with various soil parameters for different soil depths in the forest land of Jorhat district ((A1-E1): 0-30 cm; (A2-E2): 0-60 cm; (A3-E3): 0-100 cm). 

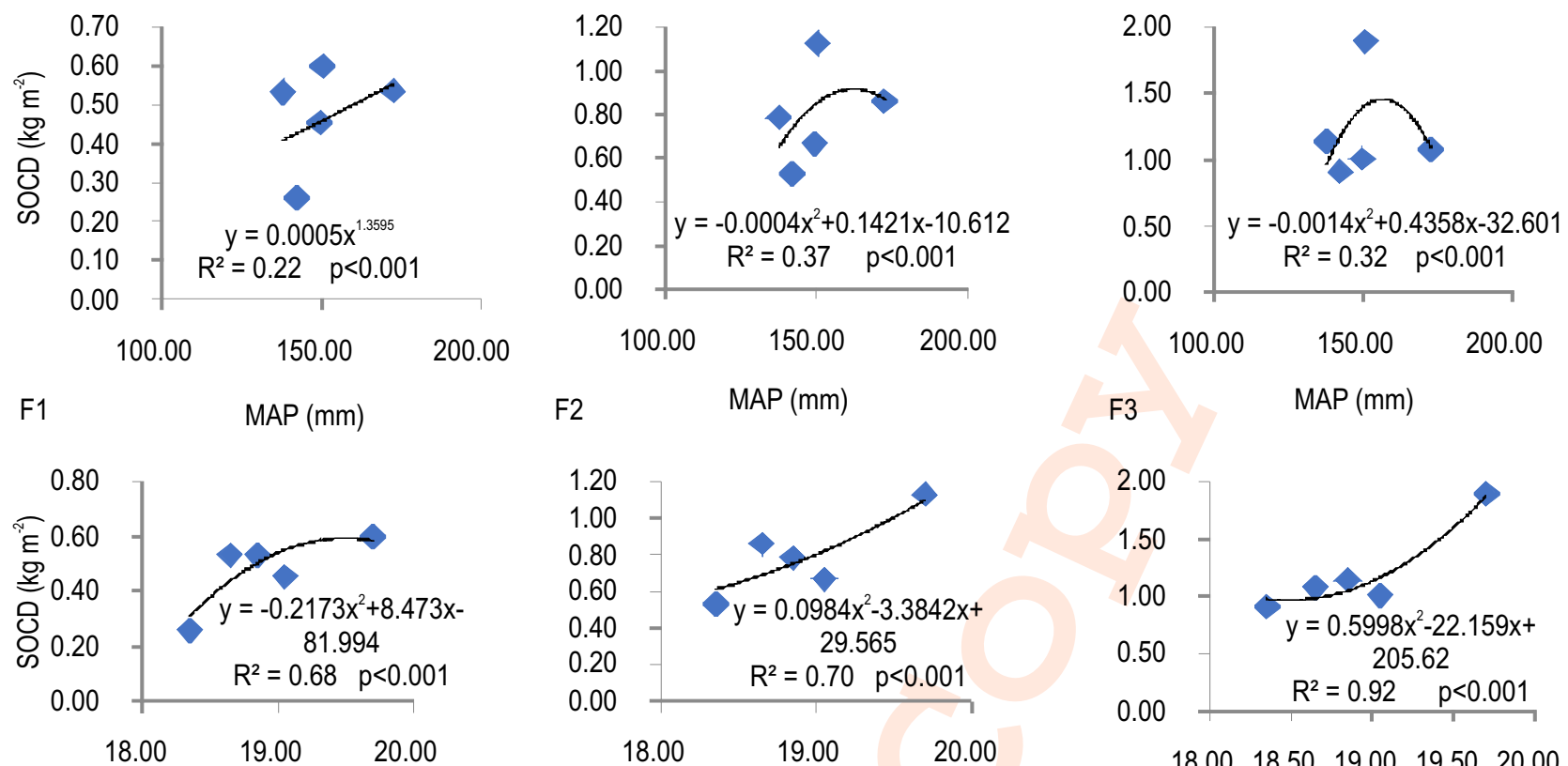

F2

$\operatorname{MAP}(\mathrm{mm})$
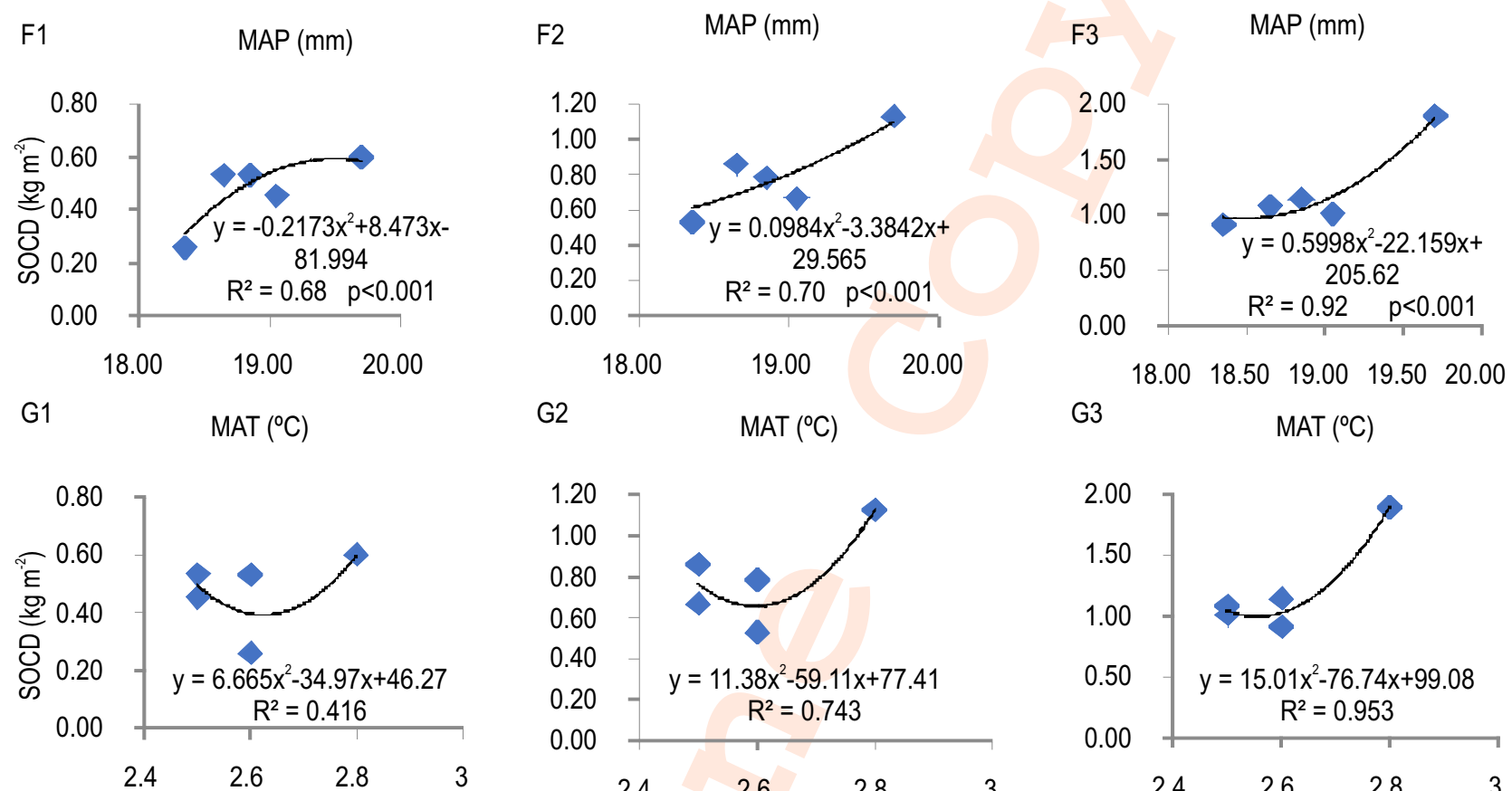

$\mathrm{H} 1$

Evaporation (mm)

$0-30$
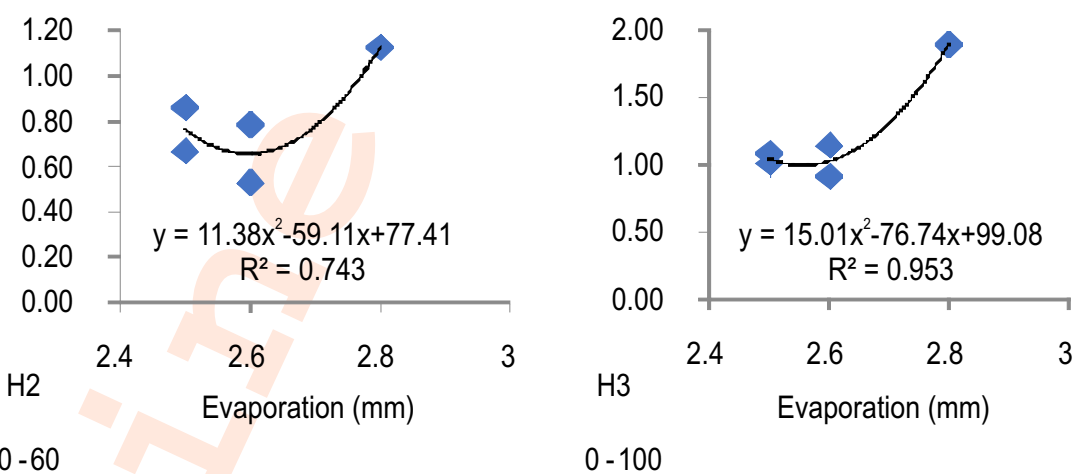

Fig. 5(b) : Relationship of SOCD with various soil parameters for different soil depths in the forest land of Jorhat district ((A1-E1): 0-30 cm; (A2-E2): 0-60 cm; (A3-E3): 0-100 cm).

except for 0-30 cm depth under paddy $\mathrm{pH}\left(r=-0.461^{* *}\right)$ showed significant but negative correlation with SOCD. The effect of $\mathrm{pH}$ on SOCD decreased with depth (Fig. 5a, 6a) for both land use systems, which can be easily observed from $R^{2}$ values of regression graphs.

A path analysis was performed to visualize the relationship of different soil parameters with SOCD. Path analysis gives a more detailed understanding of relationships among limiting factors and their contribution to SOCD. Path analysis provided quantitative insights on "contribution paths" of predictor variables to a response variable.

With path analysis, we have decomposed the correlations into direct and indirect effects. The effects are quantified with the path coefficients (Table 6a). According to the path coefficients, in soils of paddy field, the sequence of direct effects on SOCD was Clay $>$ Sand $>$ Silt $>$ CEC $>\mathrm{pH}$. Both zeroorder correlation and path analysis showed that clay content has a significant positive effect on SOCD. The direct effect on SOCD was much higher (path coefficient 1.193) than the other factors.Sand also showed the similar pattern like clay. In the zeroorder correlation, $\mathrm{pH}$ had no significant relation with SOCD but it showed positive direct effect (path coefficient 0.206) which might be due to interaction with clay. Similarly, for CEC, with almost negligible correlation with $S O C D$, it can be considered that the direct effect of CEC on SOCD (path coefficient 0.330 ) was mainly due to the contribution of collinearity between clay content and CEC (Guan et al., 2013) and it can be easily noticed from Table 6a that CEC had high positive indirect effect on SOCD through clay (path coefficient 0.845 ). Little or no zero order correlation was 

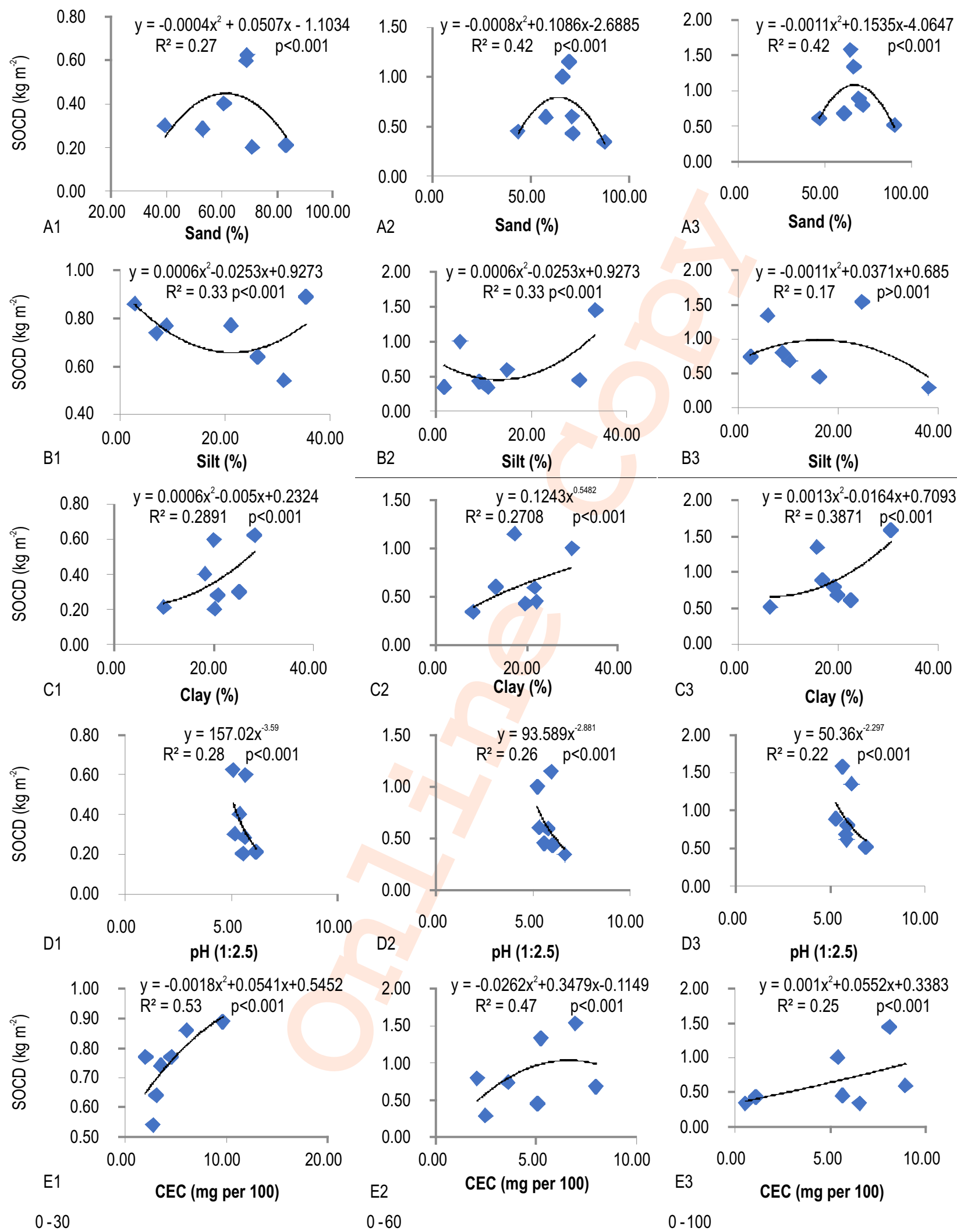

Fig. 6(a) : Relationship of SOCD with various soil parameters for different soil depths in the paddy field of Jorhat district ((A1-E1): 0-30 cm; (A2-E2): 0-60 cm; (A3-E3): 0-100 cm). 

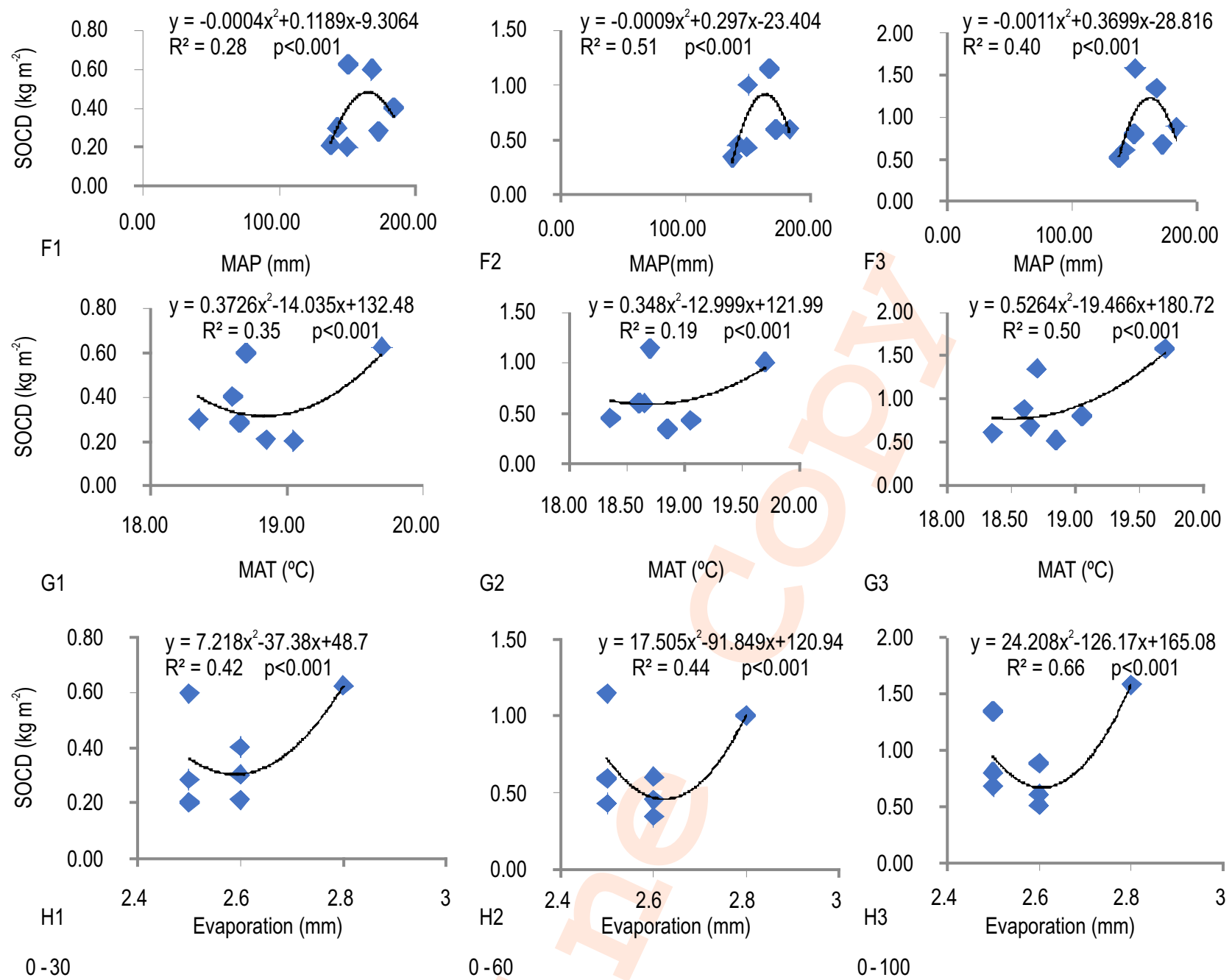

Fig. 6(b) : Relationship of SOCD with various environmental factors for different soil depths in the paddy field of Jorhat district ((F1-H1): 0-30 cm; (F2-H2): 0-60 cm; (F3-H3): 0-100 cm).

observed in case of silt and SOCD, but it showed high direct effect (path coefficient 0.916 ) as well as indirect positive effect through CEC (path coefficient 0.570) and indirect negative effect through sand (path coefficient-0.629).

In case of forest land, sequence of direct effect to SOCD was $\mathrm{CEC}>\mathrm{pH}>$ clay $>$ silt $>$ sand. Zero order coefficients of $\mathrm{pH}$ $\left.B=0.289^{* *}\right)$ and CEC $\left(r=0.368^{* *}\right)$ showed significant positive correlation with SOCD (Table 6b). The direct effect of CEC (path coefficient 1.030) on SOCD was positive and high which make it the most influencing factor in forest land. It also had indirect effect on SOCD through clay which was due to strong effect of clay on CEC. Similarly, direct effect of $\mathrm{pH}$ (path coefficient 0.806) on SOCD was high and positive due to collinearity of $\mathrm{pH}$ and clay, indirect effect of $\mathrm{pH}$ (path coefficient 0.677 ) through clay on SOCD was also high. But direct effect of clay on SOCD was very low, the medium zero order correlation $\left(r=0.440^{* *}\right)$ with SOCD was probably due to its interrelation with $\mathrm{pH}$ and CEC.
Importance of land use have been documented by many researchers in past, but apart from land use from this study soil texture was found to have more important role in determining the spatial as well as vertical distribution of SOCD. Moreover, the effect of evaporation ( $\mathrm{mm}$ ) on SOCD was recorded higher than other environmental factors under both land use for the district. Although we have no control over environmental factors, but appropriate land use strategy and sustainable soil management practices are most important interventions for creating favourable environment to increase SOC storage capacity of soil under any land use.

\section{References}

Amooh, M.K. and M. Bonsu: Effect of soil texture and organic matter on evaporative loss of soil moisture.J. Global Acad. Excell., 3, 152$161(2015)$.

Baruah, R., B.K.Medhi, D.K. Patgiri, D. Bhattacharyya and C.R. Deka: 
Soil organic carbon stock in agricultural land of Jorhat district of Assam. J. Soil Water Conser., 16, 25-31 (2017).

Blake, G.R. and K.H. Hartge: Bulk density. In: Methods of Soil Analysis, Part l: Physical and Mineralogical Methods (Ed.: A. Klute); Soil Sci. Soc. America: Madison, Wisconsin, pp.363-375 (1986).

Bouyoucos, G.J.: Hydrometer method improved for making particle size analysis of soils. Agron. J., 54, 464-465, (1962).

Chaplot, V., B. Bouahom and C. Valentin: Soil organic carbon stocks in Laos: spatial variations and controlling factors. Global Change Biol., 16, 1380-1393 (2010).

Chapman, H.D.: Cation-exchange Capacity. In: Method of Soil Analysis, Part 2: Chemical and Microbiological Properties (Ed.: C.A. Black), Am. Soc. Agron., Madison, Wisconsin, pp. 891-900 (1965).

Chen, B., X. Zhang, J. Tao, J. Wu, J. Wang, P. Shi, Y. Zhang and C. Yu: The impact of climate change and anthropogenic activities on alpine grassland over the Qinghai-Tibet Plateau. Agric. For. Meteorol.,143,11-18 (2014).

Choudhury, B.U., P.T. Das and A. Das: Land use systems and soil carbon stocks-status in North-eastern region of India. In: In soil carbon sequestration for climate change mitigation and food security. Central Research Institute for Dry Land Agriculture, Hyderabad, pp. 31-45 (2011).

Choudhury, B.U., K.P. Mohapatra, A. Das, Pratibha T. Das, L. Nongkhlaw, Abdul Fiyaz, S.V. Nagachan, S. Hazarika, D.J. Rajkhowa and G.C. Munda: Spatial variability in distribution of organic carbon stock in soils of North East India. Curr. Sci., 104, 604-614 (2013).

Dalal, R.C. and K.Y. Chan: Soil organic matter in rainfed cropping systems of the Australian cereal belt. Australian J. Soil Res., 39, 343-355 (2001).

Dikshit K.R.: Relief features of north-east India. Springer, Dordrecht, pp. 91-125 (2014).

Gangopadhyay, S.K., T. Bhattacharyya and D. Sarkar: Hydromorphic soils of Tripura: Their pedogenesis and characteristics. Curr. Sci., 108, 984-993 (2016).

Guan, Y., J. Wei, D. Zhang, M. Zu and L. Zhang: To identify the important soil properties affecting dinoseb adsorption with statistical analysis. Sci. World J., Article ID 362854, pp.1-7 (2013).

Guan, J.H., L. Dengc, J.G. Zhang, Q.Y. He, W.Y. Shi, G. Li and S. Du: Soil organic carbon density and its driving factors in forest ecosystems across a north western province in China. Geoderma, 352, 1-12 (2019).

IPCC: Good practice guidance for land use, land-use change and forestry. In: IPCC National Greenhouse Gas Inventories Programme (Eds.: J. Penman, M. Gytarsky, T. Hiraishi, T. Krug, D. Kruger, R. Pipatti, L. Buendia, K. Miwa, T. Ngara, K. Tanabe and F. Wagner). Institute for Global Environmental Strategies (IGES), Japan, 3.1-3.312 (2003).

Islam, K.K., S. Anusontpornperm, I. Kheoruenromne and S. Thanachit: Relationship between carbon sequestration and physico-chemical properties of soils in salt-affected areas, Northeast Thailand. Kasetsart J. (Nat. Sci.), 48, 560-576(2014)

Jackson, M.L.: Soil Chemical Analysis. Prentice Hall of India Pvt. Ltd., New Delhi, p. 498 (1973).
Jobbagy, E.G. and R.B. Jackson: The vertical distribution of soil organic carbon and its relation to climate and vegetation. Ecolo. Appli., 10, 423-436 (2000).

Kenye, A., U.K. Sahoo, S.L. Singh and A. Gogoi: Soil organic carbon stock of different land uses of Mizoram, Northeast India. AIMS Geosci., 5, 25-40 (2019).

Khalil, M.I. and B. Osborne: Improving estimates of soil organic carbon (SOC) stocks and their long-term temporal changes in agricultural soils in Ireland. Geoderma, 322, 172-183 (2018).

Krull, E., J. Baldock and J. Skjemstad: Soil texture effects on decomposition and soil $\mathrm{C}$ storage. In: Net ecosystem exchange: CRC Workshop Proceedings (Eds.: M.U.F. Kirshbaum and R. Mueller). CRC for Greenhouse Accounting, Canberra, pp. 103-110 (2001).

Luo, Y.Q., R. Sherry, X. Zhou and S.Q. Wan: Terrestrial carbon-cycle feedback to climate warming: experimental evidence on plant regulation and impacts of biofuel feedstock harvest. Global Change Biol.-Bioenergy, 1, 62-74 (2009).

Mao, J., K.G.J. Nierop, M. Rietkerk and S.C. Dekker: Predicting soil water repellency using hydrophobic organic compounds and their vegetation origin. Soil, 1, 411-425(2015).

Mirzaee, S., S. Ghorbani-Dashtaki, J. Mohammadi, H. Asadi and F. Asadzadeh: Spatial variability of soil organic matter using remote sensing data. Catena, 145,118-127 (2016).

Oades, J.M.: An overview of processes affecting the cycling of organic $C$ in soils. In: The role of non-living organic matter in the earth's $C$ cycle (Eds.: G.G. Zepp and C. Sonntag). Dahlem Workshop Reports. Wiley and Sons. N.Y., pp. 293-303 (1995).

Paul, E.A. and F.E. Clark: Soil Microbiology and Biochemistry. Academic Press, San Diego, p. 272 (1989).

Reichstein, M., E. Falge, D. Baldocchi, D. Papale, M. Aubinet, P. Berbigier, C. Bernhofer, N. Buchmann, T. Gilmanov and A. Granier: On the separation of net ecosystem exchange into assimilation and ecosystem respiration: Review and improved algorithm. Global Change Biol., 11,1424-1439 (2005).

Schlecht-Pietsch, S., U. Wagner and T.H. Anderson: Changes in composition of soil polysaccharides and aggregate stability after carbon amendments to different textured soils. Appl. Soil Ecol., 1, 145-154 (1994).

Uri, N.D.: Conservation practices in U.S. agriculture and their implication for global climate change. Sci. Total Environ., 256, 23-38 (2000).

Walkley, A. and I.A. Black.: An examination of the method for determining soil organic matter and proposal modification of the chromic acid titration method. Soil Sci., 37, 29-38 (1934).

Wang, G., J. Qian, G. Cheng and Y. Lai: Soil organic carbon pool of grassland soils on the Qinghai-Tibetan Plateau and its global implication. Sci. Total Environ., 291, 207-217 (2002).

Yang, Y., J. Fang, Y. Tang, C. Ji, C. Zheng, J. He and B. Zhu: Storage, patterns and controls of soil organic carbon in the Tibetan grasslands. Global Change Biol., 14, 1592-1599 (2008).

Yang, Y., A. Mohammat, J. Feng, R. Zhou and J. Fang: Storage, patterns and environmental controls of soil organic carbon in China. Biogeochemistry, 84, 131-141 (2007). 